\section{Deliberationes tudományos folyóirat}

14. évfolyam 1. szám 2021/1, 83-101.

Kézirat beérkezése: 2021.04.26.

Kézirat befogadása: 2021.08.16.

DOI: 10.54230/Delib.2021.1.83
Deliberationes Scientific Journal

Vol.14; Ed.No. 1/2021, pages: 83-101

Paper submitted: 21th April 2021

Paper accepted: 16th August 2021

DOI: 10.54230/Delib.2021.1.83

\title{
TERMELÉSMENEDZSMENT SZOFTVERES TÁMOGATÁSA EGY VÁLLALAT PÉLDÁJÁN KERESZTÜL
}

\author{
Molnár Gyula, Simon Sándor \\ Gál Ferenc Egyetem, Gazdasági Kar
}

\begin{abstract}
Absztrakt
Jelen tanulmány célja, bemutatni egy vállalkozás példáján keresztül hogyan segíti a termelésmenedzsmentet a vállalatirányítási rendszer, illetve a rendszer használata mennyire befolyásolja egy vállalkozás teljesítményét. További célkitűzés, hogy feltárjuk a vállalat informatikai fejlettsége és a vállalati működés eredményessége közötti kapcsolatokat.

Minden vállalkozás működése három alappillérre épül, függetlenül attól, hogy a vállalkozás termékek gyártásával vagy valamilyen szolgáltatás nyújtásával kapcsolatos: a pénzügyek, a termelés és a marketing.

A pénzügyi feltételek megteremtését követően elő kell állítani a terméket, illetve biztosítani kell a szolgáltatást. A termék gazdaságos gyártásáért, és/vagy a szolgáltatás megfelelő színvonalú nyújtásáért a termelésmenedzsment felel. Bár a termelésmenedzsment nevében is benne foglaltatik, hogy a menedzsment része, mégis legtöbb feladata a menedzsment és a mérnöki tevékenységek határán helyezkedik el. Végezetül, a terméket és/vagy a szolgáltatást értékesíteni kell.

A vállalkozások működése szempontjából a termelési folyamatok mellett kitüntetett szereppel bír az információkkal való gazdálkodás, hiszen a hiteles forrásból származó információk birtoklása egyfajta hatalmat, döntéshozatali képességet is jelent.

Az információgazdálkodás feladatait ma már számtalan integrált vállalatirányítási információs rendszer segíti. A piacon elérhető és megvásárolható integrált rendszerek az üzleti folyamatok valamennyi szegmensét képesek leképezni. A bevezetésük akár néhány hét alatt megtörténhet. Fontos kérdés az, hogy a vállalkozások menedzsmentje hogyan tud élni a felkínált lehetőségekkel. A téma ehhez a versenyhelyzethez való alkalmazkodás miatt került feldolgozásra.

A szakirodalomban felhalmozott tudásanyag áttanulmányozása után, megvizsgáljuk az általános és gyakorlati elvárásokat egy piaci vállalatirányítási szoftverrel szemben, a következő lépés, hogy bemutatjuk a vállalkozásban bevezetett vállalatirányítási rend-
\end{abstract}


szert és azt, hogy a bevezetése hogyan oldotta meg a bevezetést indokló problémákat.

Kulcszavak: információgazdálkodás, termelésmenedzsment, vállalati információs rendszer, ERP, versenyképesség, hatékonyságnövelés

\title{
SOFTWARE BASED PRODUCTION MANAGEMENT THROUGH THE EXAMPLE OF A COMPANY
}

\author{
Gyula Molnár, Sándor Simon \\ Faculty of Economy, Gál Ferenc University
}

\begin{abstract}
The aim of this study is to show, through the example of a company, how production management systems help production management and how the use of the system affects the performance of a company. Another goal is to explore the relationships between a company's IT sophistication and the effectiveness of its operations.

The operation of any business is based on three basic pillars, regardless of whether the business is related to the production of products or the provision of a service: finance, production and marketing.

Once the financial conditions have been created, the product must be produced and the service provided. Production management is responsible for the economical production of the product and / or the provision of the service to an appropriate standard. Although it is included in the name of production management as part of management, most of its tasks are located on the border of management and engineering activities. Finally, the product and / or service must be sold.

From the point of view of the operation of enterprises, in addition to the production processes, the management of information has a special role, since the possession of information from an authentic source also means a kind of power and decision-making ability.

Today, the tasks of information management are supported by numerous integrated corporate governance information systems. The integrated systems available and available on the market are able to map all segments of the business process. They can take up to a few weeks to implement. An important question is how business management can take advantage of the opportunities offered. The topic has been processed to adapt to this competitive situation.

After reviewing the knowledge accumulated in the literature, we examine the general and practical requirements for a corporate governance software. The next step is to present the corporate governance system implemented in the company and how its implementation solved the problems justifying the introduction.
\end{abstract}

Keywords: information management, production management, Enterprise Resource Planning systems, competitiveness, efficiency improvement 


\section{BeVEZETÉS}

Napjainkban az üzleti informatika témaköre egyre inkább a figyelem központjába kerül, amelyet az is jelez, hogy egyre több vállalat ismeri fel a fontosságát is - nem véletlenül. Az üzleti információs rendszer alkalmazása lehetővé teszi a vállalatok hatékonyabb működésének elősegítését, a döntéshozók információ ellátottságának javítását, ezen kívül jelentős szerepe lehet abban, hogy az informatikára hangsúlyt fordító vállalatok versenyelőnyre tegyenek szert. Valamennyi üzleti vállalkozás legfőbb célja a jövedelmének maximalizálása, amelyet termékek elöállítása és/vagy szolgáltatások elvégzésével ér el. Ahhoz, hogy egy üzleti vállalkozás vezetésének munkája sikeres legyen elengedhetetlen a naprakész információk birtoklása.

Vizsgálatunk célja bemutatni egy konkrét példán keresztül, hogyan segíti a termelésmenedzsmentet egy vállalatirányítási rendszer (Enterprise Resource Planning, ERP) bevezetése. További célkitűzésünk bemutatni a bevezetéséröl szóló döntések körülményeit.

\section{SZAKIRODALMI ÁTTEKINTÉS}

A termelésmenedzsment egyik funkcionális területe a menedzsmentnek, melynek küldetése közé tartozik mind a termelö- mind a szolgáltató rendszerek müködtetése. Elmondható, hogy a termelésmenedzsment missziója a menedzsment és a mérnöki cselekvések együttesének ellátása.

Termelésmenedzsment feladatát tekintve különböző megközelítések lelhetőek fel a szakirodalomban. Gaither (1990) elgondolása szerint egy konvertáló rendszer mely az input erőforrásokat átalakítja és az eredménye termék/szolgáltatás. Chase és Aquilano (1995) megfogalmazása szerint már egy komplexebb folyamatot jelöl, mely szerint annak a termelörendszernek a tervezését, a működtetését és a javítását jelenti, amely a terméket/szolgáltatást előállítja/nyújtja. Szente (2003) szerint a termelésmenedzsment a termelési folyamat eredményességét érintő tényezők hatékony irányítása, a nyersanyagok beszerzésétől kezdve egészen a késztermékeknek a fogyasztókhoz történő eljuttatásáig, tehát a transzformációs rendszer tervezésével és az áramlási folyamatok irányításával foglalkozó, döntéseken keresztül megvalósuló tevékenységsor.

\subsection{Vállalatirányítási információs rendszerek fogalma, jelentősége}

„A vállalati információs rendszer (IR) a vállalat környezetére, belső működésére és a vállalat-környezet tranzakcióira vonatkozó információk koordinált és folyamatos beszerzését, feldolgozását, tárolását és szolgáltatását végző személyek, tevékenységek, valamint a funkciók ellátását lehetővé tevő hardver- és szoftvereszközök összessége. Az információs rendszer fö összetevői az ember, mint döntés-előkészítő és döntéshozó, a külső és belső információ, valamint a külső és belső hardver, szoftver elemek és szervezeti megoldások (ún. orgver)." (Michelberger, 2002) 
Az integrált vállalatirányítási információs rendszerek biztosítják a gyorsan változó vállalati környezethez való alkalmazkodást a rugalmasság növelésével. Olyan vállalati alkalmazásokat tesznek elérhetővé, amelyek a megszerzett információ integrálásával hozzásegítik a vállalatot, az üzleti adatokból származó profit megszerzéséhez. Mindent egybevéve tehát az integrált információs rendszerek, az információ szervezett gyüjtésével, feldolgozásával, továbbításával, számítógépes terjesztésével foglalkoznak. (Orbán 2006)

Ebben pedig jelentős szerepet játszik maga az információtechnológia (IT), amely számítástechnikai és információs eszközökkel segíti az információfeldolgozási folyamatot.

A vállalati információs rendszerek bevezetésekor fontos azt az irányelvet követni, hogy a hosszú távú eredmény fontosabb, mint a rövid távú növekedés vagy nyereség. A tisztább kép kialakításához nagyban hozzájárul a megfelelően kialakított belső ellenőrzési rendszer, amely a modern vállalatirányítás egyik eszköze arra vonatkozóan, hogy a vállalati működésből eredő kockázat csökkenjen (Zörög et al., 2010). A vállalatmenedzsment szempontjából fontos, hogy összhang alakuljon ki a stratégiai és operatív célok között (Hágen-Kondorosiné, 2009).

\section{2 Általános és gyakorlati elvárások vállalatirányítási szoftverrel szemben}

Az ERP rendszerekkel kapcsolatban kiemelhető néhány általános követelmény, amelyet minden forgalomba, vagy használatba lévő rendszernek biztosítani kellene. A teljesség követelményének eleget tevő ERP rendszerek a felhasználó vállalkozás minden gazdasági folyamatát átölelik. (Raffai 2006)

A piacon lévő vállalatirányítási rendszerek moduláris felépítésűek. Ez köszönhető a piaci keresletnek (Kelenhegyi, 2004), hisz főként a tevékenység különbözőségéből adódóan a felhasználóknak különböző modulok fontosak. A rendszer modulokra bontása, bizonyos összetartozó funkciók alapján történik. Ezt alapvetően a szervezeti egységek feladatai szerint csoportosítva kell megoldani. Az ERP rendszerek többsége mégis más-más funkciókat csoportosít egy modul alá. Így hát előfordulhat, hogy az itt leírt modulok egyes rendszerekben összevontan vannak jelen, más rendszerben pedig éppen szétdaraboltan. 


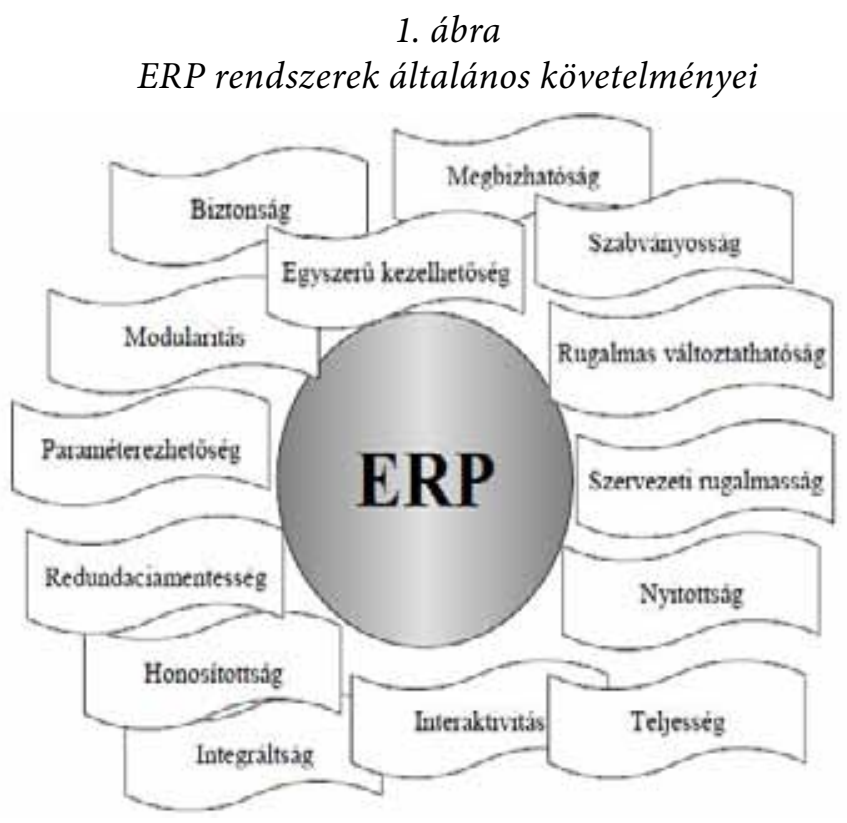

Forrás: Tóth (1999)

Az ERP rendszerek a funkcionális megközelítése mellett beszélhetünk adatmodell alapú megközelítésről, vagy akár algoritmikus megközelítésről is. A felhasználók számára azonban a legfontosabb megközelítési mód a funkció alapú. (Rózsa 2008) Az ERP funkciókat vizsgálva az alábbi nagy csoportok különböztethetők meg (Hetyei, 2004):

- Logisztikai jellegű funkciókat tartalmazó modulok: értékesítés, beszerzés, raktározás.

- Pénzügy, számvitel, kontrolling funkciókat tartalmazó modulok: pénzügyi modul (számlák, pénztár, bank), számviteli modulok (könyvelés), kontrolling modul (tervezés, elemzés).

- Gyártáshoz kapcsolódó funkciókkal rendelkező modulok: gyártástervezés, gyártásvezérlés.

- Humánerőforrás és bérkezelés: munkaerő nyilvántartás, bérkezelés, munkaerő tervezés, munkaerő toborzás, szervezet menedzsment, utazás menedzsment, rendezvény menedzsment.

- Beruházás menedzsment: beruházások nyilvántartása, beruházás tervezés.

- Alkalmazásokat átfogó funkciók: felhasználói menedzsment, adminisztráció menedzsment, táblaszintü lekérdezés menedzsment, egyedi fejlesztések. 


\subsection{Vállalatirányítási rendszerek bevezetésének elönyei}

1. Integrálja a pénzügyi információkat, azáltal hogy egy közös adatbázist használ, nagyobb rálátást tesz elérhetővé a vállalatra.

2. Integrálja a vevői információkat.

3. Standardizálja és felgyorsítja a gyártási folyamatokat.

4. A logisztikai feladatok optimalizálásával csökkenti a készletállományt.

5. Integrálhatóvá teszi az értékteremtő folyamatokat (Stratégiai vállalatirányítás Strategic Enterprise Management - SEM).

6. Biztosítja az alkalmazottak számára a vállalati információk, a vállalati tudásbázis gyors és könnyű megszerzését.

7. Nemcsak egy adott vállalat saját folyamatait képes integrálni, hanem elérhetővé teszi a vevők, szállítók, partnerek, vagy más szervezetek egyes folyamatait.

\section{ERP BEVEZETÉS AZ EMHŐ-BAUdERMANN KFT-NÉL}

\subsection{Az ERP rendszer bevezetésének háttere:}

1. Integrálja a pénzügyi információkat: a vállalat árképzése a 2012-ben kialakított szintet képviselte, így az árrés megfelelő mértékű érvényesítése is jelentős problémákba ütközött.

2. Integrálja a vevői megrendelésekkel kapcsolatos információkat: vevői kedvezmények és ajánlati árak.

3. Készletkezelés nyomon követése teljes mértékben hiányzott a logisztikai tevékenységek köréből. Hiányoztak a tényleges készletérték és készletmennyiség naprakész adatai, valamint a vevői rendelések teljesítéséhez szükséges anyagmennyiség elérhetőségének és rendelkezésre állásának meghatározása is problémákba ütközött. A beszerzési rendelések tervezhetősége sem volt megvalósítható a naprakész információk hiányában.

4. A hiányos és elavult adminisztrációs módszerek kiváltása. A vállalat tevékenységének nyomon követése kizárólag szervezetlen (ad-hoc) módon készülő és folyamatos átalakulásnak kitett Excel táblázatokon alapult. A vevői rendelések manuális, papír alapú rögzítését lehetővé tevő dokumentum az alábbiakban látható. Ezen dokumentum szolgált a továbbiakban az üzemi területen a termelés nyomon követésére, valamint a szállításkezelés adminisztrációjára is.

A használatban levő megrendelőlap hiányosságai elsősorban a speciális megmunkálásokat, valamint az alapértelmezettől eltérő színkombinációkat tartalmazó megrendelések esetén voltak leginkább szembetűnőek. Ilyen szerkezettel a megrendelőlap csak szabadszavas, kézzel írott megjegyzések segítségével tudott a gyártást végző üzem számára pontosabb gyártástechnológiai instrukciókkal szolgálni. Ezen manu- 
ális adatkezelés teljes mértékben lehetetlenné tette a cégen belüli bármilyen jellegű kontrolling tevékenységet. A megfelelő döntéstámogatási információk hiányában a kereskedelmi és termelési tevékenység tervezhetetlen volt, így az esetleges hatékonyságjavítást célzó vizsgálatok, valamint lépések is elmaradtak a vállalat életében.

\author{
2. ábra \\ Megrendelö lap
}

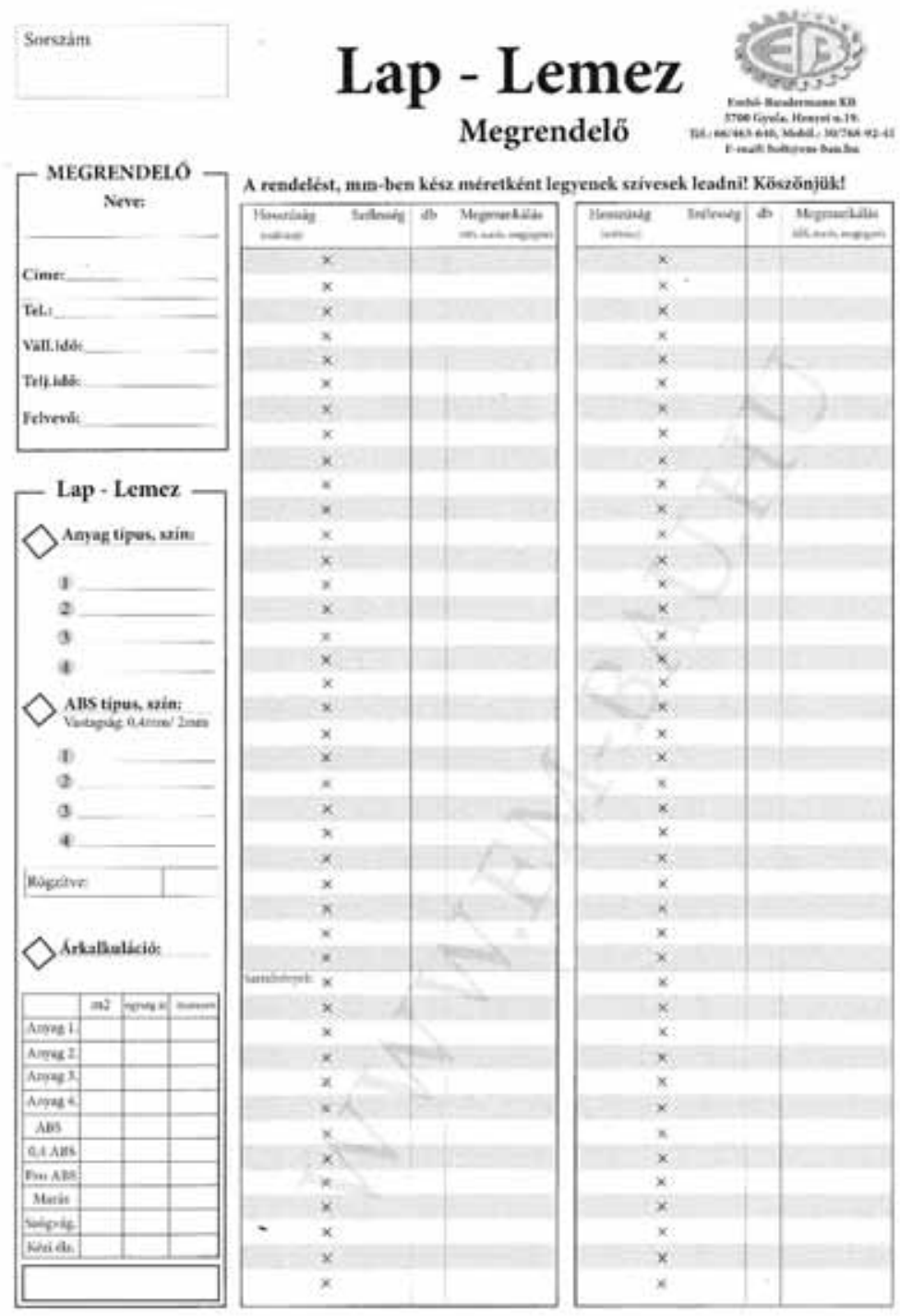

Forrás: Molnár (2020) 


\subsection{A bevezetésre kerülő ERP rendszer bemutatása}

A bevezetésre került rendszerben a vevői rendeléskezelést és a termelés nyomon követesét ellátó modulok képzik a szoftver gerincét. A rendszer funkcióinak leírása mellett képernyőfelvételekkel illusztráljuk az egyes felhasználói felületek lehetőségeit.

3. ábra

Modulok



Forrás: Molnár (2020)

\section{Partnertörzs}

Az eladások növelését segítő ügyféladatbázis felépítését a vevők alapadataival kell kezdeni. A rendszer lehetővé teszi az ügyfél törzsadatok rögzítését és automatikus betöltését külső adatbázisból.

\section{4. ábra \\ Partnerkezelés}

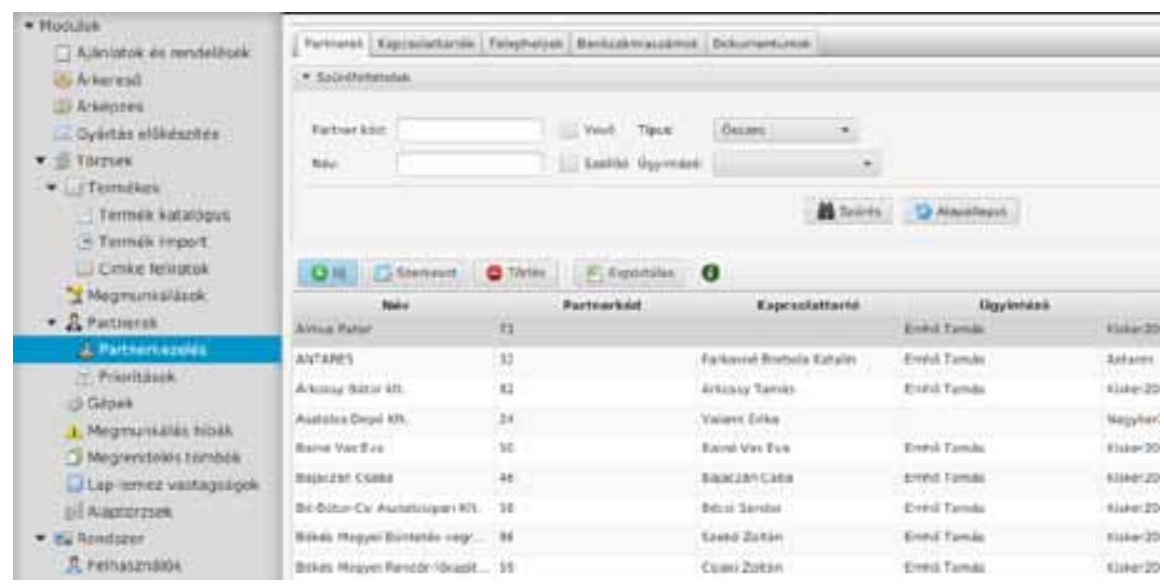

Forrás: Molnár (2020) 


\section{TERMÉKKATALógus}

A műszaki cikkspecifikáció a vevő által meghatározott termékparaméterek rögzítését és a gyártás során előállításra kerülő végtermék ellenőrzési paramétereinek rögzítését biztosítja. A rendszer lehetővé teszi technológiai utasítások, valamint müszaki rajzok dokumentumként történő kezelését is.

\section{5. ábra}

Termék katalógus

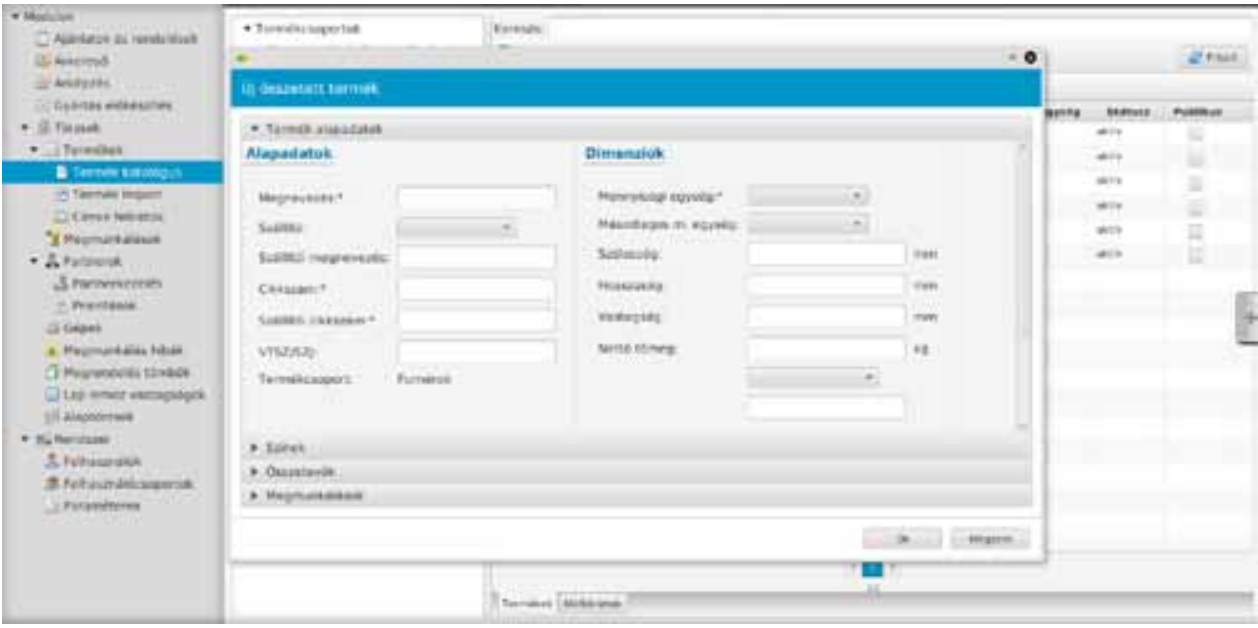

Forrás: Molnár (2020)

A végtermékek összeépülését a rendszer darabjegyzékek formájában tartja nyilván. Minden vevői cikkhez egyedi darabjegyzékek rendelhetők, melyek közül a termelés indításakor nem csak az alapértelmezett választható, hanem bármely alternatív öszszeépülési lista is.

A terméktörzs kialakítása a számlázás egyik alappillére, kitöltése elengedhetetlen, csak olyan szolgáltatásokat, termékeket lehet a számlázás során használni, amelyek ebben a törzsállományban megtalálhatók.

\section{MegmunKálásoK}

Minden megmunkálást kötelezően egy műveletcsoportba sorolunk be. A müveletcsoportok listája egy rendezett lista, azaz a rendszerben szabadon beállítható sorrend egy technológiai sorrendet ír elő, amelyet a rendszer minden munkadarab esetén ellenőriz a téves gyártási folyamat megelőzése érdekében. 
6. ábra

Megmunkálások

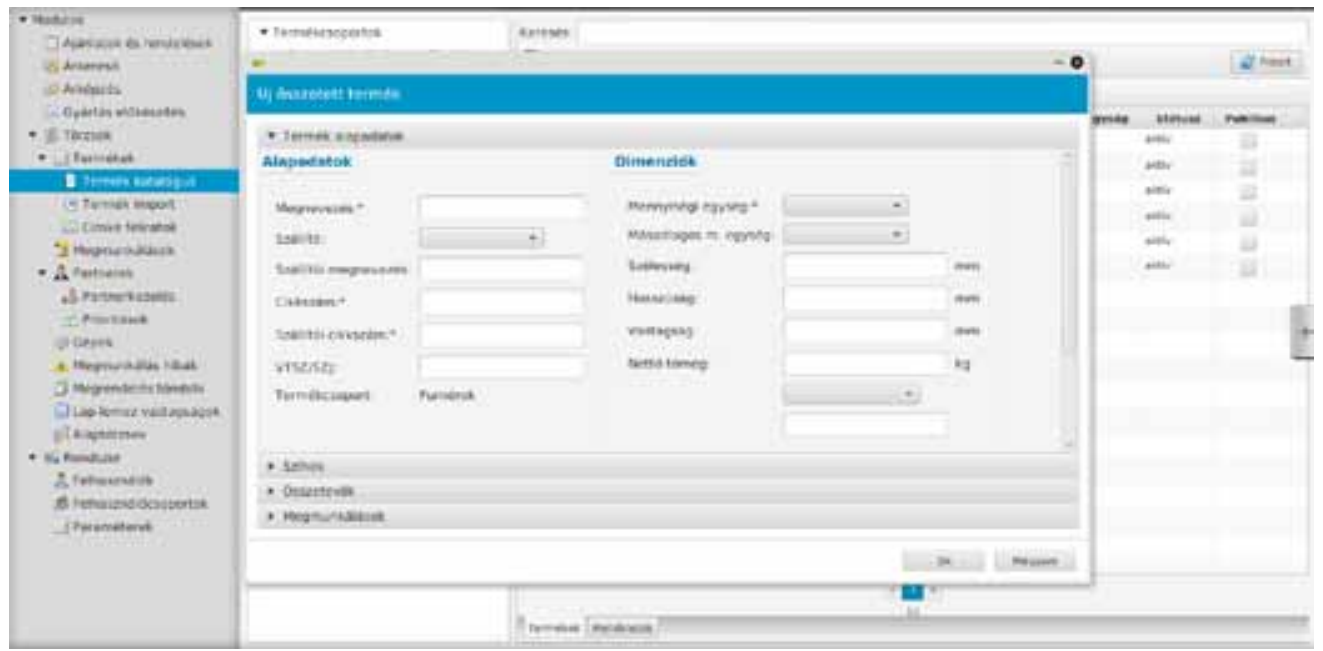

Forrás: Molnár (2020)

\section{VEVŐI RENDELÉSKEZELÉS}

Az árlisták alapvetően az alaptermékek és a megmunkálások függvényében alakíthatók ki. Az egyes partnerek különböző kedvezményekben részesíthetők már az egyes termékek vonatkozásában is.

\section{7. ábra}

Árkeresö

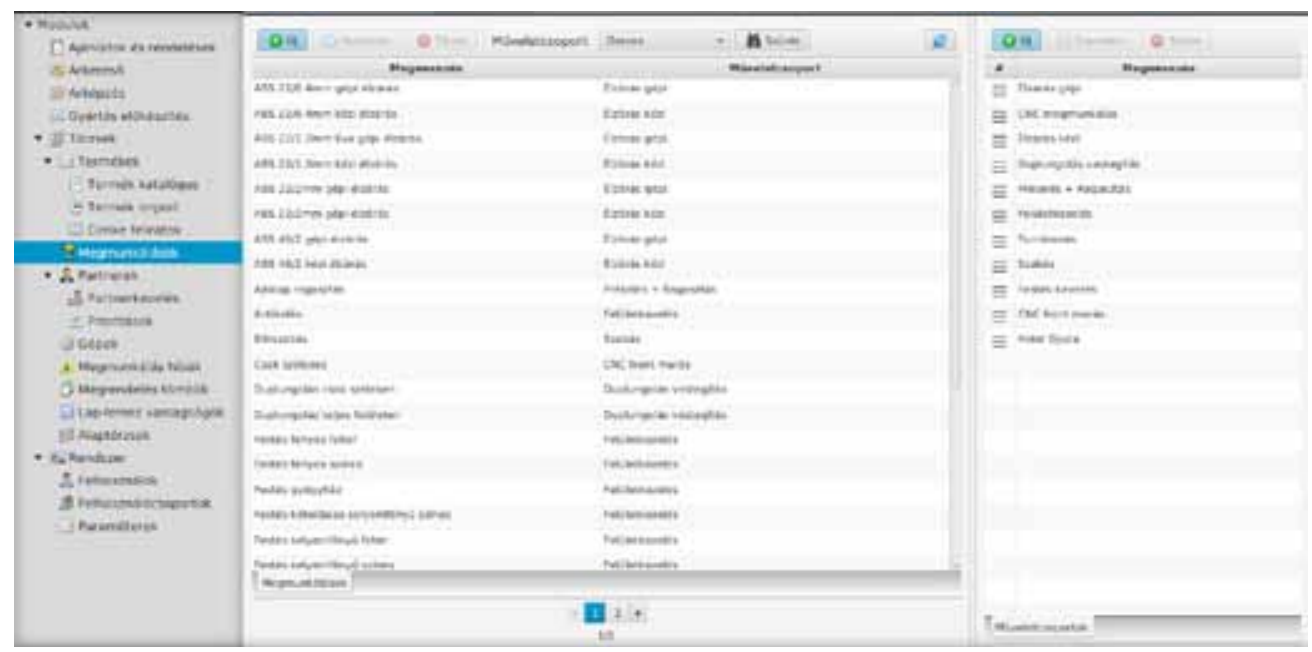

Forrás: Molnár (2020) 


\section{ÉRTÉKESÍTÉSI AJÁNLATOK}

A cég termékei iránti konkrét vevői érdeklődést vevői ajánlatkérésnek nevezzük. Az ajánlatkészítés során mind az alaptermékek, a szerelvények és a szükséges megmunkálások tekintetében a rendszer törzsadataira támaszkodva a partnerek részére személyre szabott ajánlatváltozatok állíthatók ki. Az ajánlatkészítő modul automatikus dokumentáció generálással rendelkezik, így esztétikus formátumú ajánlati dokumentáció nyújtható át az ajánlatkérő partnerek számára.

8. ábra

Ajánlat
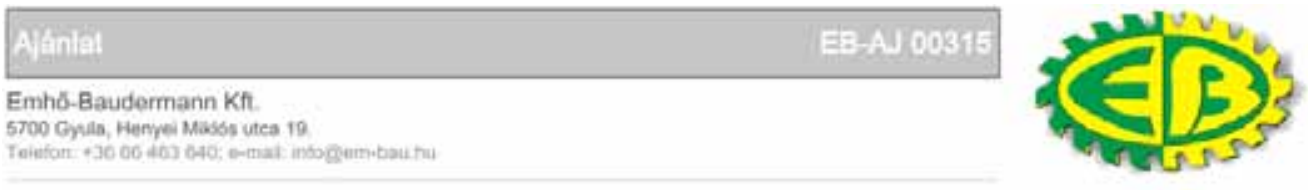

Ajánlatkérō: OROShazaGLAS Kft.

Kért hatärido: 2020.11.13.

Vallalt hataicido: 2020 11.13.

\section{Egyéb termékek}

\begin{tabular}{|c|c|c|c|c|c|c|}
\hline Megnevezbs & Cibsszam & Szln & $\begin{array}{l}\text { Neth } \\
\text { egrebir }\end{array}$ & Monnyis6g & Mdrtokegysde & Noego de Seaszesen \\
\hline Foged mutadedap & $\infty .01$ & & 1074 & & & 147401 \\
\hline Oevenen & & & & & & 147401 \\
\hline
\end{tabular}

Forrás: Molnár (2020)

A megrendelések modul a teljes körü vevői igények rögzítését teszi lehetővé. A megrendelések tételekre - ún. munkalapokra - oszthatók. A munkalapok biztosítják a gyártási folyamat nyomon követhetőséget a rendszerben.

A végtermékre vonatkozó gyártási paraméterek beállítására is lehetőség nyílik, például szélesség, hosszúság, mennyiség. A vállalati rendszerbe befogadott megrendelések és a létrehozott munkalapok listájáról e-mail alapú visszaigazolás küldhető ki a megrendelők számára, amely tartalmazza az egyes munkadarabokhoz tartozó azonosító számot is.

A megrendelöhöz hozzárendelt árlisták közül választva lehet a munkalapok, így a teljes megrendelés, árazását automatikusan elvégezni. 


\section{ÉRTÉKESÍTÉSI MEGRENDELÉSEK}

A modul célja az egyszerűbb, hatékonyabb értékesítést támogató munkavégzés lehetővé tétele. A rendszer támogatja az értékesítők munkáját az adott, teljes értékesítési folyamatra vonatkozóan: Ajánlat -> Rendelés -> Szállítás -> Számlázás

9. ábra

Ajánlatok és rendelések

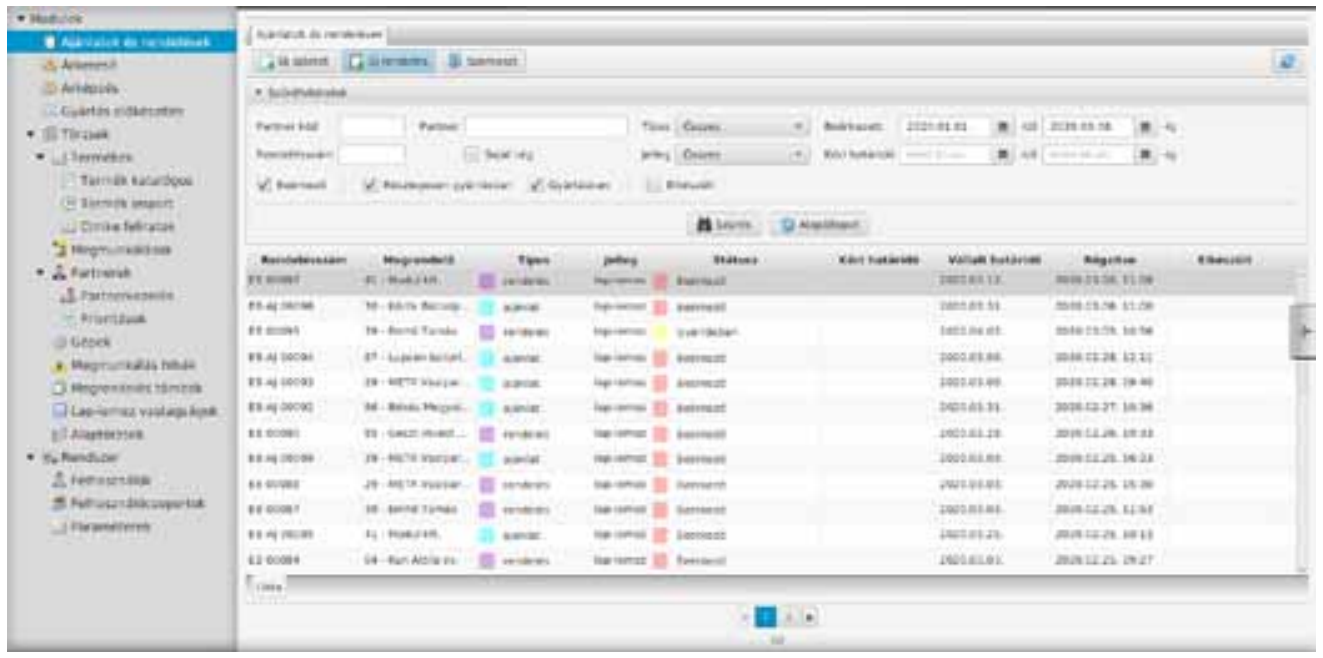

Forrás: Molnár (2020)

A rendszer emellett lehetővé teszi az alábbiakat:

1. gyártásból érkező előrejelzések kezelése;

2. potenciális értékesítési lehetőségek kezelése és nyomon követése, kereskedelmi feladatok támogatása;

3. ajánlatkészítés támogatása;

4. ajánlati árazás, többszintű kedvezmény rendszer kezelésének biztosítása több szinten.

A rendszer alkalmas a kedvezmény-rendszerek és azok kombinációinak kezelésére:

1. mennyiségi kedvezmények;

2. egyedi árak;

3. értékhatárhoz kötődő kedvezmények;

4. időszaki kedvezmények. 
10. ábra

Ajánlatok és rendelések 2.

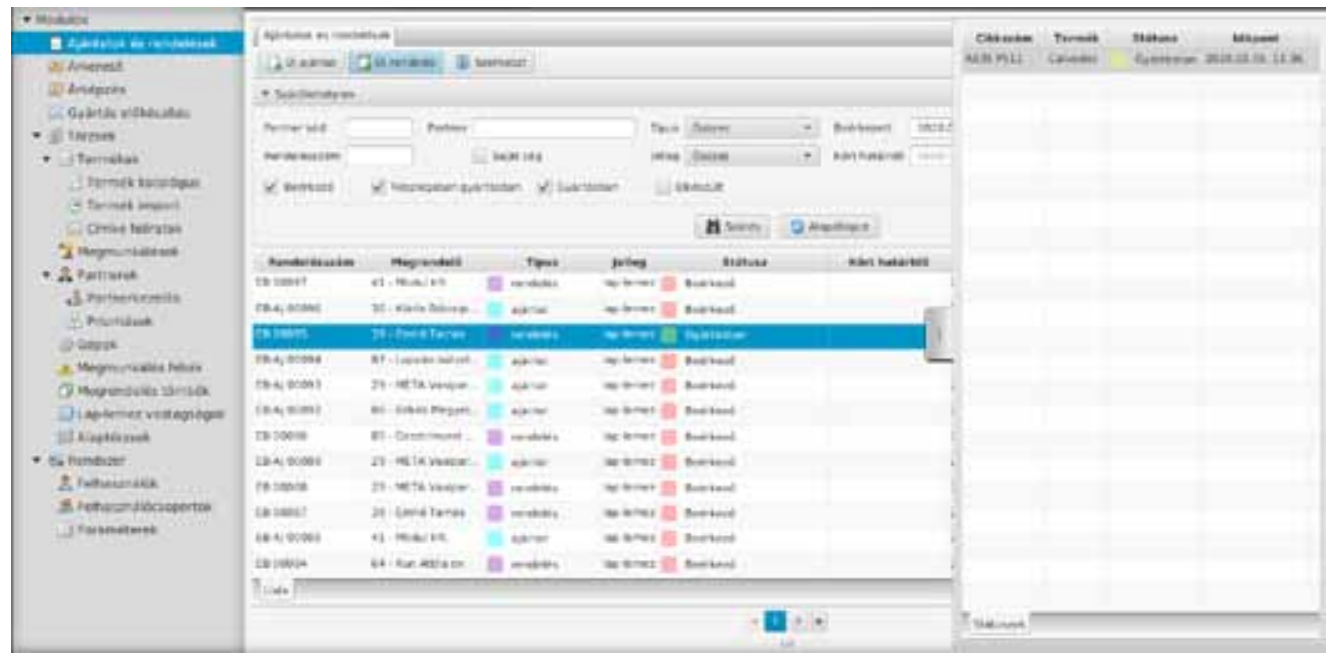

Forrás: Molnár (2020)

Megrendelés tételek felvétele az alábbi módokon lehetséges:

1. Termékek az árukészletből, előrendelések (ha nincs elegendő készlet) $\mathrm{Az}$ árukészlet adatbázisból válaszhatók ki a megrendelt termékek. Ha az adott termékből jelenleg nincs készleten, akkor az előrendelésként fog felkerülni a megrendelölapra.

2. Szolgáltatás, munkadíj táblázatból

Munkadíjak, szolgáltatások, költségek táblázatból válaszható ki az a tétel, ami a megrendelölapra fog kerülni.

3. Manuálisan, begépeléssel

4. Bizományi elszámolás

Bizományban lévő termékek felvétele egy összesített bizományosi elszámolási táblázatból.

5. Eszközbérlés 
11. ábra

Megrendelés (saját szerkesztés)
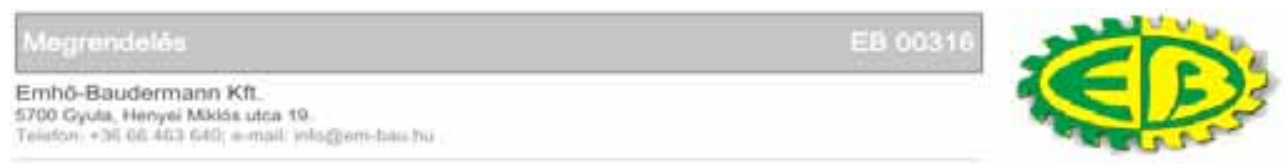

Megrendelō: Csapó Bútor kft.

Kert hatairido: 2020.11 .04 .

Vallat hatando: 2020.11.04.

Tételek

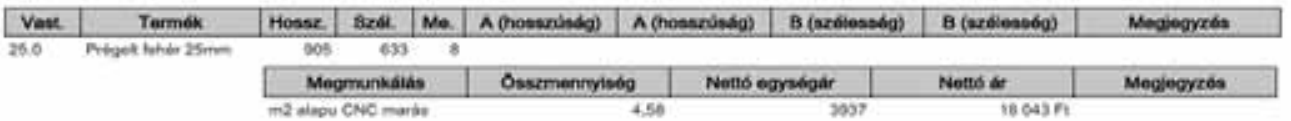

Lap-lemez termékek összesen

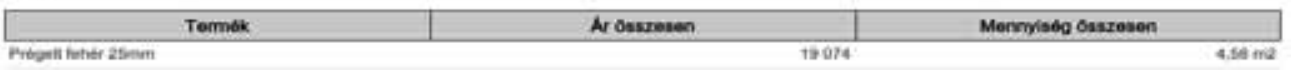

Forrás: Molnár (2020)

A vevő átutalásos fizetési módja esetén vevői tartozás keletkezik, melynek kiegyenlítését szigorúan figyelnünk kell. E tevékenység külön nyilvántartás, az úgynevezett vevői számla nyilvántartás létrehozását igényli. A vevői tartozás kiegyenlítésének szokásos útja a banki átutalás (amennyiben nem készpénzes számla volt), amely mint kiegyenlítési mód vevői követelést jelent. A vevői tartozások sorsának követése megköveteli, hogy a vevői követelések is szerepeljenek a nyilvántartásban.

\section{TERMELÉSMENEDZSMENT}

A beérkező rendelések a termelési szakaszba kétféle módon kerülhetnek ki:

1. A megrendelés adataiból generált PDF-formátumú dokumentum kinyomtatásával.

2. Táblagép alapú mobilapplikációban, ún. elektronikus munkalapon. 


\section{2. ábra}

Gyártás előkészités (saját szerkesztés)

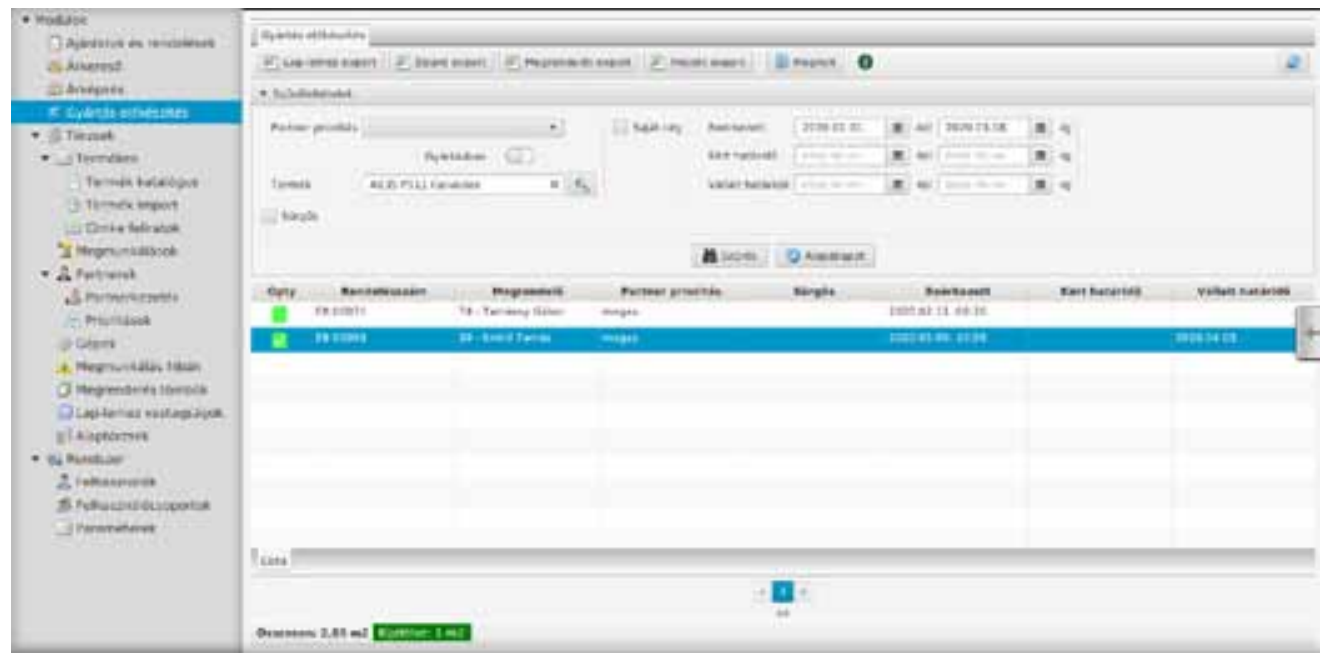

Forrás: Molnár (2020)

A rendszer lehetővé teszi a gyártások ütemezését, javaslatot tesz a gyártási folyamatok sorrendiségére, az egymást követő gyártások prioritására, munka és erőforrás szükségletére. Figyelembe veszi a technológiai sorrendi korlátozások kezelését.

\section{3. ábra}

Gyártás előkészités 2.

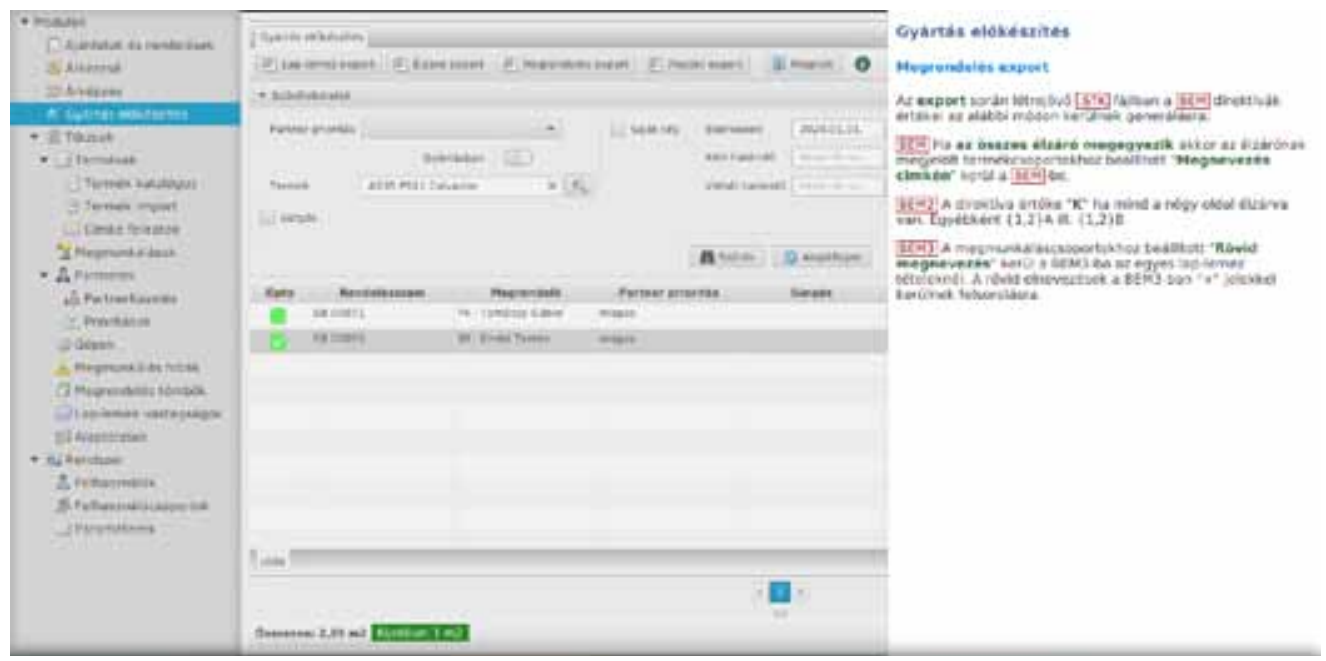

Forrás: Molnár (2020) 
A gyártási szám/sarzsszám kezelésének célja a raktári készletek, gyártott termékek nyomon követhetőségének elősegítése, a szavatossággal rendelkező tételek felhasználásának optimalizálása. A rendszer lehetővé teszi sarzs és gyártási számok generálását automatikus és/vagy manuális módon, majd az egyedi azonosító számok nyomon követését. A sarzs, más néven köteg szám - több, egy gyártásból beérkező cikk együttes azonosítását szolgálja. A gyártási szám - cikkenként különböző, egyedi azonosítást tesz lehetővé.

A gyártáselőkészítés további célja a késztermék alapanyag szükségletének rögzítése és kezelése. A rendszer lehetőséget biztosít az egyes késztermékek előállításához szükséges alapanyag-mennyiségek megadására, illetve ezen mennyiségek tetszőleges módosítására.

\section{4. ábra}

Gyártás előkészités 3.

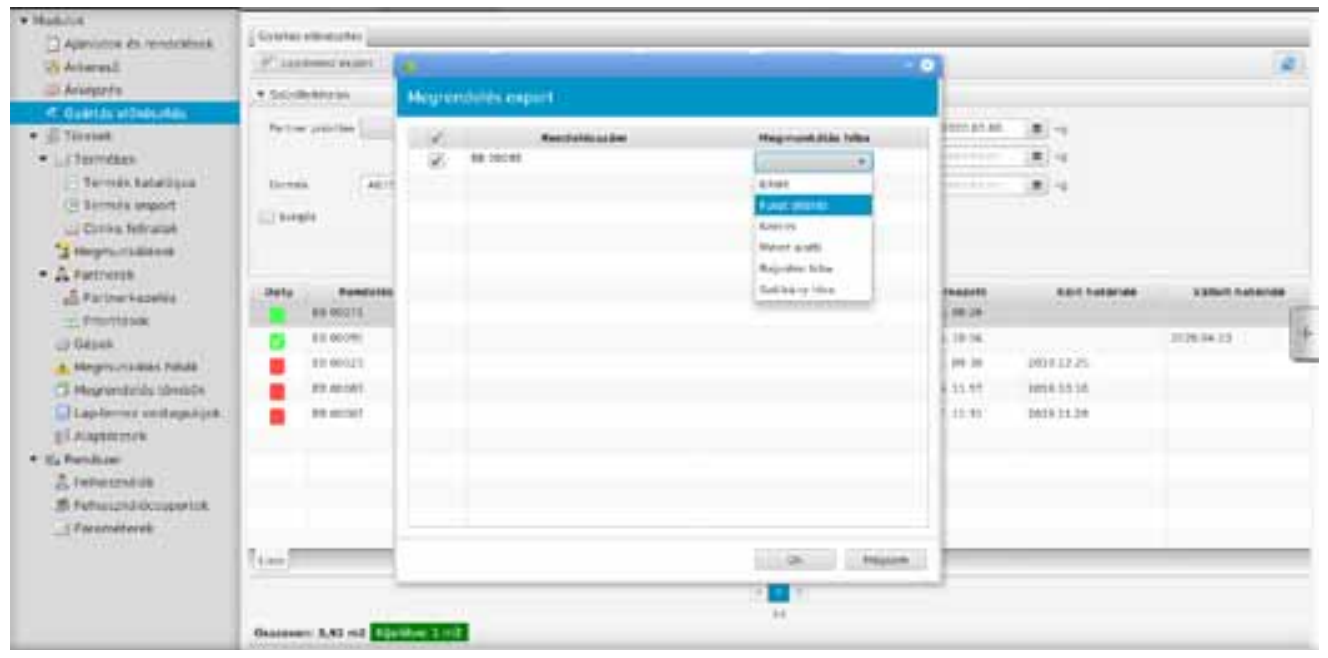

Forrás: Molnár (2020)

A termelési tevékenység indítása a belső rendelések vagy gyártási lapok alapján történik, mely a beszerzési és kereskedelmi tevékenységet végző felhasználók számára visszaigazolást is jelent a termelés által vállalható határidők és gyártható mennyiségek vonatkozásában. A termelés indítása során a szükséges alapanyagok a gyártásközi raktárba kerülnek egy raktári kiadólap segítségével. A gyártási szakaszok befejezését követően a lejelentések során az arra jogosult felhasználó választhat a normál, a döntésre váró, valamint a selejt jellegü lejelentések közt.

A rendszerben lehetőség van a teljes megrendelések exportjára az ún. „Opty” rendszer valamint egy külső számlázó rendszer számára. Az „Opty” rendszer az alapanyagok felhasználásának leghatékonyabb módját biztosítja. A vállalati rendszerben elkészített munkalapok teljes körü adattartalma elérhető egy táblagépre megvalósított applikáció segítségével. 
Az elektronikus munkalapot megvalósító applikáció többes célt lát el. Alkalmas az ún. gyüjteménykezelésre, mellyel az egyes raktárhelyek közti mozgásokat valamint a külső telephelyen történő megmunkálások nyomon követését teszi megoldottá. Az applikáció segítségével az üzem területén online elérhetők a megmunkálásra várakozó munkadarabok alapadatai, valamint a hozzájuk tartozó müszaki rajzok is.

A rendszer lehetővé teszi, hogy akár vonalkódolvasás, akár felhasználói interakció segítségével az egyes megmunkálások elindításának és befejezésének ténye naplózható legyen.

\section{5. ábra}

Opty rendszer

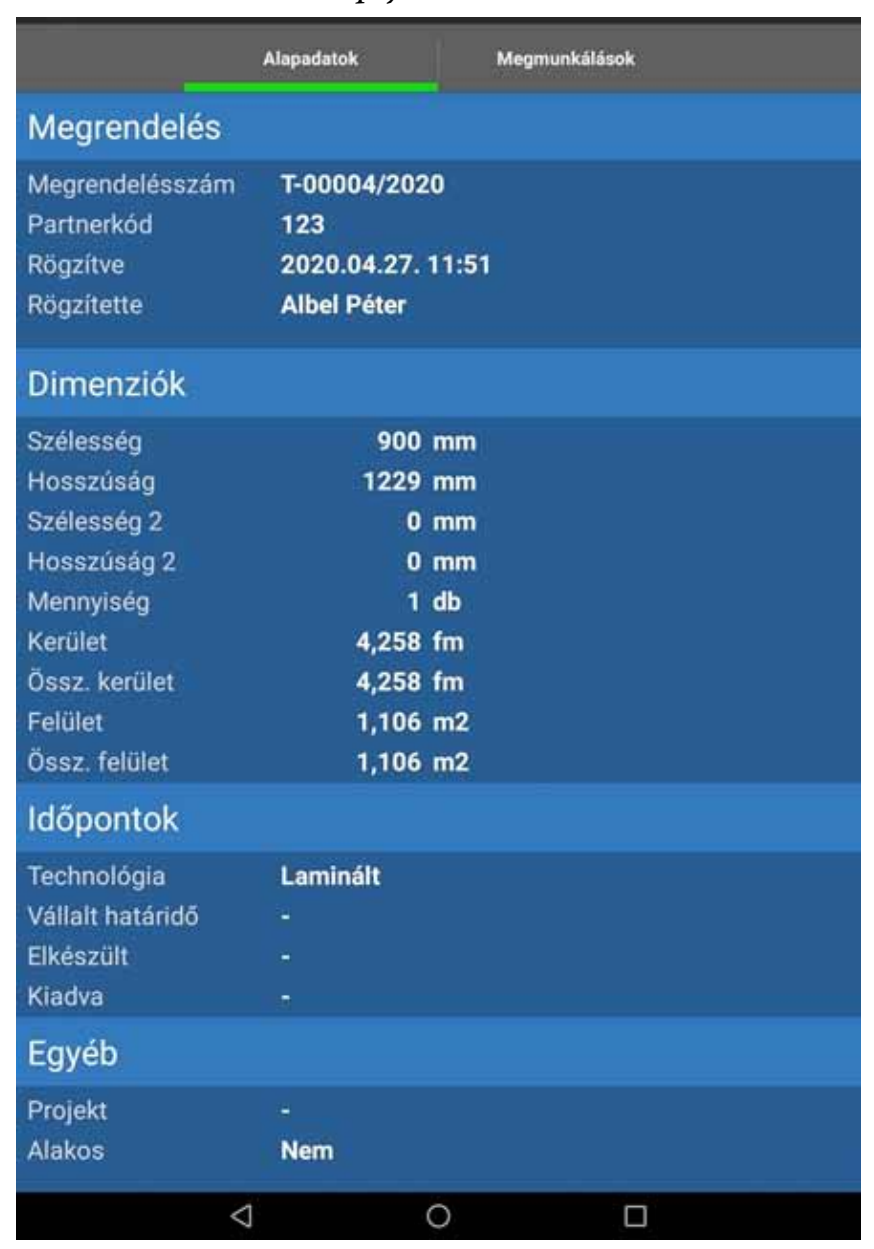

Forrás: Molnár (2020) 


\section{KöVETEZTETÉSEK ÉS JAVASLATOK}

A rendszerben kialakított funkciók a teljes vállalati tevékenységet olyan mértékben tudták lefedni, hogy a tevékenységekről rögzített tranzakciók adataira alapozott statisztikák és lekérdezések megfelelő minőségü vezetői döntéshozatalt tudnak támogatni az arra jogosult vállalati felhasználók számára. Ezen adatok és információk birtokában már a pénzügyi, készletgazdálkodási, termelési és logisztikai folyamatok nagy valószínűséggel költséghatékonyabbá és általánosan jobb minőségűvé tudtak válni a rendszer bevezetését követően. A vállalati információs rendszerben az alábbi döntéstámogató statisztikák azok, amelyek ezen hatékonyságnövelö eredményeket biztosítani tudják:

1. Anyagfelhasználás. Termékre, partnerre, megrendelésre, megmunkálásra vetítve az összmennyiség.

2. Átfutási idők: Termék, partner, megmunkálásra vetítve a megrendelések átfutási ideje.

3. Értékesítés: Termékenkénti, termékcsoportonkénti és partnerenkénti bontásban az értékesítési volumen.

4. Megmunkálások: A megmunkálások összidőtartama és összmennyisége partnerre és termékre vetítve, megmunkálásonkénti bontásban.

5. Munkaterhelés: Adottidőszakra vonatkozó elvégzett megmunkálásmennyiség. Az információk partner, termék és megmunkálás vonatkozásában nyerhetők ki a rendszerből.

Összefoglalóan megállapítható, hogy az Emhő-Baudermann Kft esetében az ERP rendszer kiemelkedően támogatja a vállalkozás irányítási rendszerét, azaz e vállalkozásnak kimondottan szüksége van egy vállalatirányítási és az azt támogató informatikai rendszerre is ahhoz, hogy müködése hatékonysága növekedjen, és sikeresen végre tudja hajtani a vállalati stratégiája irányelveit.

Kapcsolattartó szerző:

Corresponding author:

Simon Sándor Sándor Simon

Gál Ferenc Egyetem, Gazdasági Kar 5600 Békéscsaba

Bajza u. 33.

simon.sandor@gfe.hu

Faculty of Economy, Gál Ferenc University

Bajza str. 33. 5600 Békéscsaba, Hungary simon.sandor@gfe.hu 


\section{IRODALOMJEGYZÉK}

\section{Önálló könyv:}

Chase, R. B., and Aquilano, N. J. (1995). Production and Operations Management. Manufacturing and Services. Irwin

Hágen, I., Kondorosi, F. (2009). Üzleti tervezés, „Controll 2003” Kft. Debrecen

Kovács, I. (2011). Integrált vállalatirányitási rendszerek. Szent István Egyetem.

Szente, B. (2003). Termelés és szolgáltatásmenedzsment, Universitas-Győr Nonprofit

Sziray, J., Gaul, G. (2006). Vállalati információs rendszerek I. Széchenyi Ist ván Egyetem

Sziray, J., Gaul, G., Erdős, F. (2006). Vállalati információs rendszerek II. Széchenyi István Egyetem

Vermes, P. (2006). Termelésmenedzsment [Oktatási segédlet a műszaki menedzser szak hallgatói számára]. Szolnoki Főiskola Műszaki és Mezőgazdasági Fakultás

Gaither, N. (1990). Production and Operations Management. A Problem-Solving and Decision-Making Approach. The Dryden Press

Hetyei, J. (2004). ERP rendszerek Magyarországon a 21. században. Computerbooks, Budapest

Kelenhegyi, P. (2004). Úton az ERP felé, IT-Business 08. szám, 2004. október 12.

Koltai, T. (2006). Termelésmenedzsment. Typotex Kiadó.

Michelberger, P. (2002). Termelő és szolgáltató vállalatok információs rendszerei, Budapesti Müszaki Főiskola Keleti Károly Gazdasági Főiskolai Kar

Molnár, Gy. (2020). Termelésmenedzsment szoftveres támogatása egy vállalat példáján keresztül [Bsc Szakdolgozat]. Gál Ferenc Egyetem

Orbán A. (2006). Vezetői információs rendszerek a közigazgatásban

Raffai, M. (2006). Az információ - szerep, hatás, menedzsment, Palatia, Győr

Rózsa, T. (2008). Kis- és középvállalkozások számitógépes információs rendszereinek funkcionális, hatékonysági és gazdasági elemzése [Doktori disszertáció]. Debreceni Egyetem

Soós, T. (2013). Technológiával támogatott vállalkozások, Kiadó: Kis-Tóth Lajos

Zörög, Z. (2012). A vállalati információs rendszerek, mint gazdasági eröforrások és az alkalmazásukhoz szükséges munkaerö kompetenciák [Doktori disszertáció]. Debreceni Egyetem 